\title{
Drivers Of Customer Loyalty In South African Retail Stores
}

\author{
Dr. Chengedzai Mafini, Vaal University of Technology, South Africa
}

Prof. Manilall Dhurup, Vaal University of Technology, South Africa

\begin{abstract}
There remains a need to provide empirically derived and updated information on the influence of store image factors on both the satisfaction as well as the loyalty of customers that is specifically customised to the South African context. This study examined the relationship between store image factors, store satisfaction and customer loyalty in the South African retail environment. The study tests a conceptual framework which links five store image factors; namely, sales assistance, store atmospherics, store appeal, promotion and store accessibility to store satisfaction and customer loyalty. A four section structured questionnaire was administered to a conveniently drawn sample of 489 apparel shoppers. Participants were recruited at three shopping malls located in Gauteng Province, South Africa. Data analysis was conducted using the Statistical Packages for the social Sciences (Version 21.0). Spearman correlations showed negative to weak correlations between the factors and store satisfaction. Regression analysis revealed that promotion and store appeal were statistically significant in predicting store satisfaction. Store satisfaction was positively associated and significantly predicted customer loyalty. The findings of the study can be used by managers in retail stores to develop a current view of the shopping behaviour of today's consumers. This enables them to initiate and implement appropriate marketing strategies in their retail stores.
\end{abstract}

Keywords: Store Image Factors; Sales Assistance; Store Atmospherics; Store Appeal; Promotion; Store Satisfaction; Customer Loyalty; South Africa

\section{INTRODUCTION}

$\theta$ outh Africa has some of the largest retail enterprises in the world, and is the largest economy in Africa. The retail sector in the country continues to grow exponentially, as evidenced by the increase in the number of new shopping malls. This growth attracts questions regarding how retailers can satisfy the needs of diverse shoppers who patronise these malls daily. The worldwide retail industry itself is subject to frequent unpredictable undercurrents, which normally result in changing expectations and needs of shoppers (Sinha \& Banerjee, 2004). Other pressures facing the retail sector include socio-demographic changes, the expanding number of dual income families and increasing levels of Internet marketing (Sinha, Banerjee \& Uniyal, 2002). Consequently, the expectations and demands of consumers during their shopping experiences have changed significantly (Kim, 2002). As observed by Oh, Fiorito, Cho and Hofacker (2008), the shopping decisions (e.g. store choice) made by contemporary consumers are systematic rather than haphazard. These decisions are premised on an assortment of individual, social and store image-related factors among others (Lamb, Hair, McDaniel, Boshoff \& Terblanche, 2010). This creates the need for retailers to formulate strategies of meeting the needs of these sophisticated consumers in order to boost sales.

The purpose of this study was to examine the structural relationship between store image factors, store satisfaction and customer loyalty in the retail environment. According to McKeever (2011) store selection criteria tend to be situation specific and are typically subjected to shifts over time. Different store types or categories present consumers with an array of choices when selecting the store in which to shop (Carpenter \& Brosdahl, 2011). Vast scope for research in this area still remains then, which is driven by the need to continuously understand the factors influencing purchase decisions among shoppers in the South African context. Coupled with this is the fact that empirical evidence on issues regarding store environment is still dominated by studies conducted in Western 
settings. It is also interesting that the greater part of store environment research has disregarded key issues regarding how diverse store environment signals individually or collectively influence consumers' merchandise value perceptions and how those perceptions, in turn, influence store patronage (Broekemier, Marquardt \& Gentry, 2008). Further to that, it has been noted there are many competing choices and a lack of clarity associated with the issue of competing stores in the retail industry (Schiffman \& Kanuk, 2009). It is also necessary to point out that this study proposes a conceptual framework which is yet to be tested empirically. This study is therefore intended to occupy these existent research gaps.

The present study is significant in that an understanding of the dynamics surrounding consumers' choice may assist retailers in becoming more responsive to consumers' need for information during their search and evaluation efforts. Such knowledge may also assist in distinguishing the elements that contribute to customer satisfaction from those that sustain customer loyalty, thereby suggesting an appropriate allocation of resources (Blackwell, Miniard \& Engel, 2006). As suggested by Karpova, Hodges and Tullar (2007), a lack of knowledge about the needs and wants of consumers can create a string of strategic, functional and operational difficulties for retailers. Moreover, understanding how consumers assess quality and the factors influencing their purchase decisions may aid retailers and marketers in selecting what merchandise to stock as well as in promoting their business (De Klerk \& Lubbe, 2008).

\section{REVIEW OF RELATED LITERATURE}

\section{Store Image Factors}

Simply stated, store image may be defined as the symbolic, experiential expression of the manner in which consumers see or visualise a store (Saraswat, Mammen, Aaja \& Tewari, 2010). Retail stores have images of their own images that serve to influence the perceived quality of the products they carry and the decisions of consumers regarding store choice (Schiffman \& Kanuk, 2009). The image of a retail outlet is important in such a decision because the consumer may be seeking a particular brand or quality of merchandise, specific services such as credit or delivery, an attractive outlet, courteous employees, and an outlet where other consumers with similar lifestyles are likely to shop (Foxall \& Yani-de-Soriano, 2005). Store image represents to the consumer a composite picture of the retailer and it is one of the most powerful tools in attracting and satisfying consumers (du Preez, Visser \& Van Noordwyk, 2008a). A study conducted by du Preez, Visser and Van Noordwyk (2008b) classified store attributes into eight dimensions; namely, atmosphere, convenience, facilities, institutional, merchandise, promotion, sales personnel and service. An earlier study by Amine and Cadenat (2003) also identified the store appearance, its employees and promotional materials as noticeable cues to consumers that contribute to their perception of a store's image. In the present study, five of these store image factors; namely, store assistance, store atmospherics, store appeal, promotion and store accessibility receive empirical attention.

\section{Sales Assistance and Customer Satisfaction}

Moschis, Ferguson and Zhu (2011) identify sales assistance, which relates to the availability of store personnel who wait to assist customers, as one of the principal store image factors. Studies by Gundala (2010) and Clodfelter (2010) concluded that consumers usually patronise stores where they find experienced sales personnel who are friendly, supportive, attentive and courteous when shopping for clothing. Helpful and knowledgeable sales personnel in a store have a positive effect on consumers' perception of store image and that makes store personnel one of the crucial elements in retailing (Hu \& Jasper, 2006; Hu, 2011). As such, to have sufficient, well trained and skilled sales personnel in the retailing sector, especially the apparel sector creates a competitive advantage over those who lack in such provisions (Grewal, Baker, Levy \& Voss, 2003; Dalwadi, Rathod \& Patel, 2010). Ghosh et al. (2010) also concur that sales assistants in retail stores should have sufficient knowledge of the products offered, and must also be willing and capable of responding. Based on the foregoing evidence, the following hypothesis is suggested:

$\mathbf{H}_{1:}$ There is a significant relationship between sales assistance and customer satisfaction. 


\section{Store Atmospherics and Customer Satisfaction}

Kotler (1974) was among the early researchers to acknowledge the importance of store atmospherics and defined it as the design of environments in order to produce emotional effects in the customer with the intent to enhance the purchasing probability. According to Hoffman and Turley (2002), atmospherics consist of both tangible elements (furniture/equipment) and intangible elements (lights, scent, colour, temperature) that comprise the service experience. Store atmosphere can be divided into four sub elements; namely, exterior variables, store layout, interior display and general interior Berman and Evans (2010). Atmospherics form the first impression of the store and influence consumers' perceptions towards a store, and that also impacts on a stores' image and consumers' expectations of the retailer's offerings (Oh et al., 2008). A number of scholars (Du Preez \& Van der Vyver, 2010; Petermans \& Van Ceempoel, 2010; Thenmozhi \& Dhanapal, 2011) concluded that store atmospherics and ambience characteristics are influential determinants of store choice and satisfaction. In an earlier study by Moye and Giddings (2002) it was found that store atmospherics which includes store interior (attractive, fashionable, stylish decorations, lightings, temperature) seem to have a positive direct influence on shopping behaviour in various clothing stores. Venter and Dhurup (2005) found that customers attach great importance to the atmospheric variable (physical aspects), the reliability and the policies of the retailer. North and Croeser (2006) suggest that shoppers seek stores that have a pleasant atmosphere. Chan and Chan (2008) also emphasise that a pleasant store atmosphere helps consumers to have an exhilarating shopping experience. Another study conducted by Fiore, Yah and Yoh (2000) reveals that atmospherics affect sensory pleasure as well as components of affective pleasure (emotional pleasure) and cognitive pleasure (seeing oneself in the fantasy). Foxall and Yani-de-Soriano (2005) further argue that shoppers feel delighted when retailers offer luxurious shopping surroundings. Therefore, the following hypothesis is proposed:

$\mathbf{H}_{2}$ : There is a significant relationship between store atmospherics and customer satisfaction

\section{Store Appeal and Store Satisfaction}

The elements associated with store appeal factor relate to the variety of brands marketed by the store, the appeal of in-store displays, the appeal of the entrance of the store, the appeal of the exit of the store, the proximity of the store in relation to others and the attractiveness of exterior design which shoppers interact with while visiting shopping malls (Ibrahim \& Najjar, 2008). These aspects contribute to the uniqueness of the store (Terblanche \& Boshoff, 2006). Tlapana (2009) opines that a store that is able to communicate product information via in-store display assists consumers to make-informed purchase decisions. Even merchandise that is seen as less attractive is more likely to be purchased when displayed together with popular brands (Aspfors, 2010). Appealing store interiors and exteriors which are integrated with an appealing in-store display of various brands are therefore necessary factors that promote engagement from consumers (Moerloose, Antioco, \& Palmer Lindgreen, 2005). Koksal (2007) observed that store appeals were among the most important attributes when choosing a retails store and results in the satisfaction of customers. Hassan, Muhammad and Abu Bakar (2010:180) found that consumers tend to choose a store that offers reasonable prices, a variety of merchandise and personalised services as well as attractive interiors. Basing on these insights, the following hypothesis is put forward:

$\mathbf{H}_{3}$ : There is a significant relationship between store appeal and store satisfaction

\section{Promotion and Store Satisfaction}

Promotions have been defined as the coordination of all seller-initiated efforts to set up channels of information and persuasion to sell goods and services or promote the idea (Belch \& Belch, 2001). Promotion has also been identified as one of the significant attributes of apparel store image (Visser, du Preez \& Van Noordwyk, 2006). Promotion includes the timely announcement of sales, availability of special offers, the availability of exclusive brands and availability of branded labels (Van der Vvyer, 2008). According to Collins-Dodd and Lindley (2003) retailers could easily improve the perceptions of their customers by promoting or marketing exclusive brands with a high image which could also open up huge opportunities to differentiate themselves from other retailers. Vipul (2010) adds that consumers are more likely to purchase from a retailer that runs promotions on some of their merchandise. Research undertaken by Nazish, Rizvi and Malik (2011) also affirms that sales promotions have a 
direct positive impact on store satisfaction. A study conducted by Volle (2001) reveals that intensive promotional activity allows the store to increase its turnover, the frequency of visits and the amount of time spent in the store. Lichtenstein, Burton and Netemeyer (1997) suggest that store promotion can be a good draw card for some customers, as they build excitement in the store to stimulate purchases. It is therefore important for marketers to optimise promotional campaigns in order to inspire positive attitudes from their customers, which boosts the sales volumes of their brands (Kotler \& Keller, 2006). This leads to the following hypothesis:

$\mathbf{H}_{4}$ : There is significant relationship between promotion and store satisfaction

\section{Store Accessibility and Store Satisfaction}

Consumers' store choice decision is greatly influenced by store accessibility and location (Yan \& Eckman, 2009). According to Levy and Weitz (2009) store location and size are the prime consideration when consumers decide where to shop and location can also be used to develop sustainable competitive advantage by retailers. Martinez-Ruiz, Jeminez-Zarco \& Izquierdo-Yusta (2011) posit that shopping location is amongst the significant determinants in store choice, because location nearer consumers' home reduces transactional cost (transport cost and time spent) associated with the purchase. Jain and Bagdare (2009) view location of the store as one of the basic element of convenience. For many shoppers, convenience is essential, the speed and ease that consumers can make contact with retailers (finding the merchandise they seek quickly) powerfully influence their retail choice (Bianchi, 2009). For example, consumers may select a store at shopping mall because of proximity with other stores (Kimani, Kagira, Kendi, Wawire \& Fourier, 2012). Time pressure and cost implications also drive consumers to seek accessible shopping (Clodfelter, 2010). The closer the consumers are to a store, the greater the possibility to buy from that store (Prasad \& Aryasri, 2011). Ligas and Chaudhuri (2012) stressed that lack of convenient accessibility affect consumers' level of commitment to the store which might be reflected in customer loyalty. Accessibility is therefore important for a retail outlet as it signifies convenience and reach for the store which allows consumers to shop easily (Huang, Oppewal \& Mavondo, 2012). The following hypothesis is therefore suggested:

$\mathbf{H}_{5}$ : There is a significant relationship between store accessibility and store satisfaction

\section{Store Satisfaction and Customer Loyalty}

Veloutsou, Gilbert, Moutinho and Goode (2005) define store satisfaction as the consumer's fulfillment response, which is a judgment that a product or service feature, or the product or service itself, provides a pleasurable level of consumption related to fulfillment, including levels of under-fulfillment or over-fulfillment. Antecedents of store satisfaction include courteous and knowledgeable employees, accuracy of billing, good value for money, and quick service to have a positive effect on store satisfaction (Yi \& La, 2004), quality of services (Martinez-Ruiz et al., 2010); convenient location, experience of the store reliability, price, product quality and service quality all influence satisfaction (Lu \& Lukoma, 2011), price, acceptable product assortment and employee's overall services (Huddleston, Whipple, Mattick \& Lee, 2009).

Customer loyalty was defined by Jones, Reynolds and Arnold (2006) as the deeply held commitment to rebuy or repatronise a preferred product or services consistently in the future from the same store. Consumers express loyalty by revisiting the same store and that is measured by the ratio of the time spent at a single store irrespective of the offerings in competing stores (De Wulf \& Odekerken-Schroder, 2003). A study conducted by Knox and Denison (2000) identified three dimensions of customer loyalty; namely, the likelihood to continue shopping in the future, likelihood of purchasing other categories of merchandise in the future and the willingness to recommend the store to friends and peer groups. Drivers of customer loyalty include factors such availability of wide choices, time pressure and accessibility (East, Hammond, Harris \& Lomax, 2000). In general, retailers can benefit from loyalty; because loyal customers can provide more repeat business, serve as a source of information, cross purchase other products in the store, and they also cost less to serve (Bowen \& Chen, 2001).

Store satisfaction is viewed as an important antecedent of customer retention; which is defined as the future propensity of a customer to stay loyal with the same organisation (Saeed, Niazi, Arif \& Jehan, 2011). Retaining existing customers requires that they be satisfied with the products they bought and used (Cant, Brink \& Brijball, 
2006). In conjunction with the benefits of customer satisfaction, Chen-Yu et al. (2002) found that satisfaction increases the possibility of positive future actions which includes the increased frequency of purchase and positive word-of-mouth. Furthermore, Gundala (2010) highlights that customer loyalty is built through customer satisfaction that is built against the backup of the store image, which denotes retailers must ensure that they portray positive image in the eyes of consumers. The foregoing discussion seems to add credence to the view that store satisfaction has a positive relationship with customer loyalty. This leads to the following hypothesis;

$\mathbf{H}_{6}$ : There is a significant relationship between store satisfaction and customer loyalty

\section{CONCEPTUAL FRAMEWORK}

Based on the review of related literature, the conceptual framework illustrated in Figure 1 was developed. The framework shows a positive linkage between store satisfaction and five store image factors which are; sales assistance, store atmospherics store appeal, promotion and store accessibility. As the relationship further cascades downwards, store satisfaction is assumed to be positively linked to customer loyalty.

Figure 1. Conceptual framework for the relationship between store image factors, store satisfaction and customer loyalty

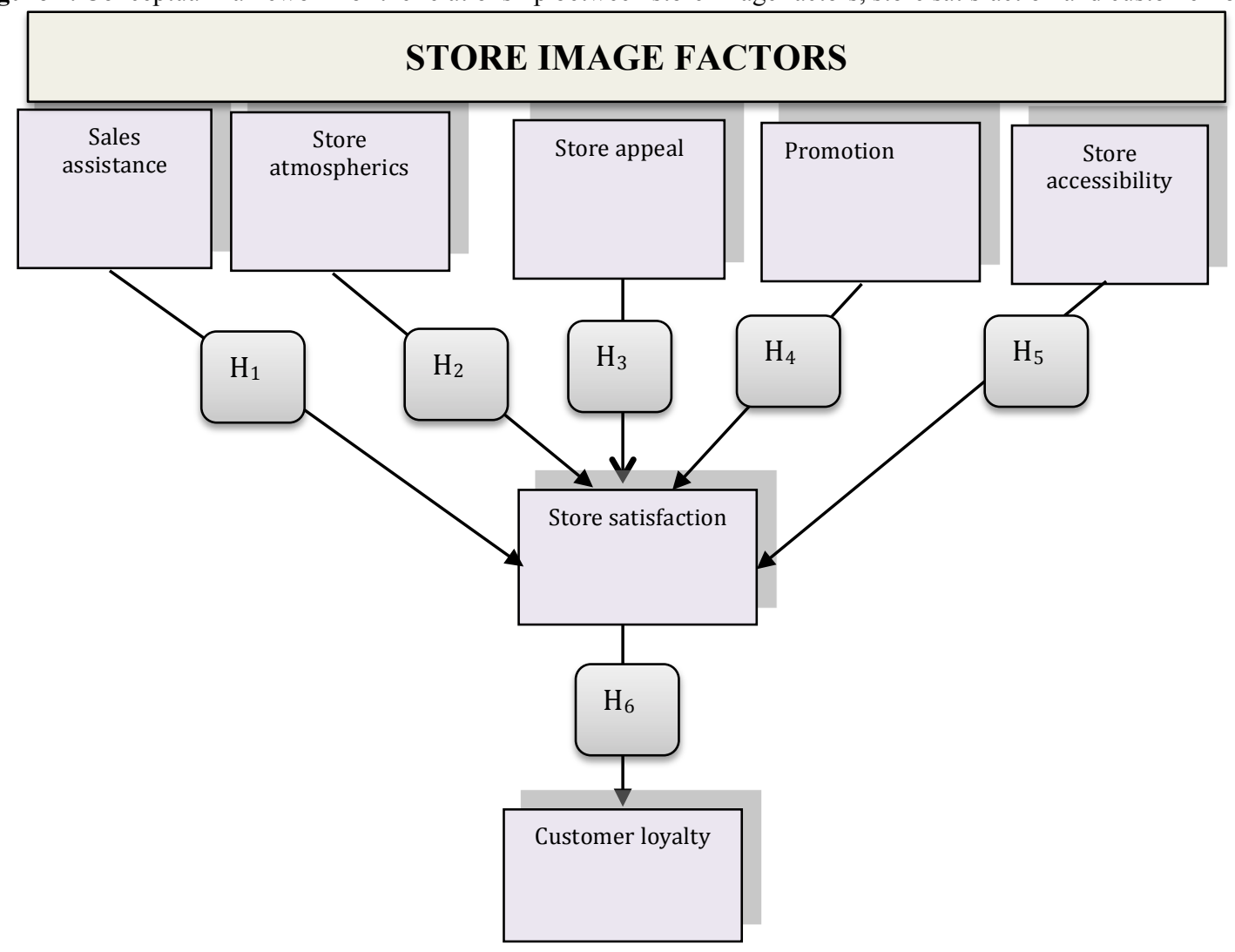

RESEARCH METHODOLOGY

\section{Research Approach and Participants}

A quantitative approach using the survey technique was adopted in which sportswear shoppers, aged at least 18 years were requested to participate. Participants were drawn from three shopping malls; namely, Protea Gardens Mall, Southgate Mall and Jabulani Mall, which are located in Gauteng Province, South Africa. Since there was no sampling frame, participants were recruited using the convenience sampling technique. The sample size was determined using the historical approach. In this regard, a number of previous studies (Oates, Shufeldt \& Vaught, 
1996; Sherman, Mathur \& Smith, 1997; Kucukemiroglu, 1999; Morschett, Swoboda \& Foscht, 2005; Carpenter \& Moore, 2006; Wirtz, Mattila \& Tan, 2007) were used as reference points in pegging the initial sample size at 600 respondents.

An analysis of the biographical profile of the participants showed that $51 \%$ of respondents $(n=250)$ were male whereas $49 \%(n=239)$ were female. A majority of the respondents $(45.2 \% ; n=221)$ were aged between 20 and 29 years. In terms of marital status, approximately $67.1 \%(\mathrm{n}=328)$ of the respondents were single. Additionally, the largest group of respondents $(58.1 \%$; $\mathrm{n}=284)$ earned less that $\mathrm{R} 100000$ per annum. Most respondents $(34.8 \%$; $\mathrm{n}=170$ ) purchased sneakers more than other types of sports apparel.

\section{Measurement Scales}

A self-administered four-section structured questionnaire was used as the data collection instrument. The questionnaire was administered using the mall intercept survey approach. Section A consisted of 41 questions that elicited participants' views on the influence of store image factors. These questions, which were placed on a seven point Likert scale anchored by 1 denoting extremely unimportant and 7 denoting extremely important, were adapted from previous studies undertaken by Lu and Rucker (2006), Van der Vyver (2008), Rigopoulou and Tsiotsou (2008) and Reutterer \& Teller (2009).

Section B consisted of 12 questions (adapted from Bloemer \& de Ruyter, 1998; Solvang, 2007) which elicited information on customer loyalty. These questions were placed on a five point Likert scale with 1 denoting highly unlikely and 5 denoting highly likely. Section C consisted of eight questions (adapted from Evanschitzky, Iyer \& Caemmerer, 2008; Mattsson, 2009; Grover, Dutta \& Chakraborty; 2011) which elicited information on store satisfaction. The questions in Section $\mathrm{C}$ were also based on 5 point Likert scales with 1 denoting strongly disagree and 5 denoting strongly agree. Section D contained dichotomous and multiple-choice questions which elicited information on the demographic attributes of respondents.

\section{Data Collection Procedures}

Administration of questionnaires was conducted on-site between the $6^{\text {th }}$ of November and the $12^{\text {th }}$ of December, 2012. Data collection was conducted with the aid of four trained fieldworkers, who were supervised by the principal researcher. Furthermore, participation in the survey was strictly voluntary. Out of the 600 questionnaires that were initially distributed, 489 questionnaires were successfully completed and eventually used in the actual data analysis, giving a return rate of approximately $82 \%$, which was deemed acceptable.

\section{Analysis of Data}

After using simple descriptive statistics to analyse the sample composition, exploratory factor analysis conducted to establish the factors that contributed to store selection among sportswear consumers. Thereafter, Spearman's correlation tests and regression analysis were employed to test the degree of association as well as causality between the factors. These analyses were conducted using the Statistical Packages for the Social Sciences (SPSS - version 21.0).

\section{RESEARCH RESULTS}

\section{Validity and Reliability}

The present study adopted Churchill and Brown's (2007) conceptualisation of validity as the extent to which differences in scores on a measuring instrument reflect true differences among individuals, groups, or situations in the characteristics that it seeks to measure, or true differences in the same individual, group, or situations from one occasion to another. Content and face validity of the instrument were ascertained by requesting three academics whose lines of expertise center on retail management to review the questionnaire. In addition, the questionnaire was pilot tested using a group of 40 conveniently selected respondents, as prescribed by Zikmund and Babin, (2010). Using the feedback from the three reviewers as well as the pilot study, a number of changes were 
made to the questionnaire. This ensured that the final questionnaire was clearer and more suitable for data collection purposes.

Using the recommendation by Shao (2002), Spearman's Correlation was adopted for the purposes of testing for convergent validity. In the correlation coefficient (Table 3) statistically significant positive relationships among the dimensions of store selection and store satisfaction and loyalty were observed, which confirms convergence. Predictive validity was tested using regression analysis (McDaniel \& Gates., 2010). The results, reported in Tables 4 and 5, respectively, showed significant relationships among the factors, thereby providing evidence of predictive validity. Construct validity was assessed through the reliabilities of the factors and was measured using Cronbach alpha coefficient (Table 1). A noteworthy observation is the high Cronbach alpha values (above 0.70), which attests to the satisfactory levels of construct validity in the present study.

\section{Exploratory Factor Analysis}

In the present study, store image factors were extracted using exploratory factor analysis, which is an approach used to identify underlying dimensions among a set of factors (Aaker, Kumar \& Day, 2007). Scale purification was conducted in which low factor loadings, cross-loadings and low communalities were eliminated in order to improve "interpretability of the factor structure" (Malhotra 2010:643). A minimum cut-off of 0.50 was used on the variable loadings (Hair et al., 2010). The Bartlett's test was significant at $\mathrm{p}<0.000$ inferring that the variables were uncorrelated, which confirmed that exploratory factor analysis could be conducted in the study. The Bartlett's test produced a chi square value $\left(\chi^{2}\right)$ of $12318.601(\mathrm{df}=630)$ and a KMO value of $0.958(>0.50)$ which also confirmed that the data were suitable for factor analysis. The results of the rotated component matrix, percentage of variance explained by each factor, cumulative percentage of variance and eigen value criterion were assessed. Ultimately, a five-factor structure was established as the items were logically associated with the underlying factors. The operational definitions of the extracted factors as well as those for store satisfaction and customer loyalty are given in Table 1.

Table 1. Factor, factor description, reliability and operational definitions

\begin{tabular}{|c|c|c|c|}
\hline Factor & Factor description & $\begin{array}{l}\text { Reliability } \\
\alpha\end{array}$ & Operational definitions \\
\hline 1 & Sales assistance & 0.81 & $\begin{array}{l}\text { It refers to elements such as the appearance of sales personnel, sales } \\
\text { personnel's willingness to assist customers, the treatment offered to } \\
\text { customers, personalised attention and the ability to effectively and } \\
\text { efficiently attend to customers' requests. }\end{array}$ \\
\hline 2 & Atmospherics & 0.79 & $\begin{array}{l}\text { This factor focuses on tailoring of the designed environment to improve } \\
\text { the chance of desired effects or outcomes }\end{array}$ \\
\hline 3 & Store appeal & 0.71 & $\begin{array}{l}\text { It relate to the variety of brands carried by store, the appeal of in-store } \\
\text { displays, the appeal of the entrance of the store, the appeal of the exit of } \\
\text { the store, the proximity of the store in relation to others and the } \\
\text { attractiveness of exterior design which shoppers interact with while } \\
\text { visiting shopping malls }\end{array}$ \\
\hline 4 & Promotion & 0.74 & $\begin{array}{l}\text { It includes the timely announcement of sales, availability of special offers, } \\
\text { the availability of exclusive brands and availability of branded labels }\end{array}$ \\
\hline 5 & Store accessibility & 0.77 & $\begin{array}{l}\text { It refers to the consumers level of perceived store convenience and } \\
\text { accessibility as these two influence their shopping behaviour }\end{array}$ \\
\hline \multicolumn{2}{|c|}{ Store satisfaction } & 0.84 & $\begin{array}{l}\text { It refers to the consumer's fulfillment response, which is a judgment that a } \\
\text { product or service feature, or the product or service itself, provides a } \\
\text { pleasurable level of consumption related to fulfillment, including levels of } \\
\text { under or over fulfillment }\end{array}$ \\
\hline \multicolumn{2}{|c|}{ Customer loyalty } & 0.81 & $\begin{array}{l}\text { It refers to the likelihood that customers are to repurchase from the same } \\
\text { store }\end{array}$ \\
\hline \multicolumn{2}{|c|}{ Overall scale } & 0.79 & $\mathrm{~N} / \mathrm{A}$ \\
\hline
\end{tabular}

As reported in Table 1, Cronbach alpha values for the scales ranged between 0.71 and 0.84 . The overall Cronbach alpha for this study was 0.79 (reported in Table 1), which is above the 0.70 threshold recommended by Hair et al. (2010). This result illustrates that the scales used in the study were internally consistent. 


\section{Statistical Descriptors of Store Image Factors}

Table 2 reports on the number of items, eigen value, percentage of variance explained, cumulative percentage, mean scores and mean score rankings of store image factors.

Table 2. Factor descriptors, number of items, eigen values, percentage of variance explained, cumulative percentage, mean scores and mean score ranking of store image factors

\begin{tabular}{clcccccc}
\hline Factor & $\begin{array}{c}\text { Factor } \\
\text { descriptor }\end{array}$ & $\begin{array}{c}\text { Number } \\
\text { of items }\end{array}$ & $\begin{array}{c}\text { Eigen } \\
\text { value }\end{array}$ & $\begin{array}{c}\text { Percentage of } \\
\text { variance explained }\end{array}$ & $\begin{array}{c}\text { Cumulative } \\
\text { percentage }\end{array}$ & $\begin{array}{c}\text { Mean score } \\
(\bar{x})\end{array}$ & $\begin{array}{c}\text { Position in mean } \\
\text { score rank }\end{array}$ \\
\hline $\mathbf{1}$ & Sales assistance & 6 & 16.11 & 44.74 & 44.74 & 5.08 & 1 \\
\hline $\mathbf{2}$ & $\begin{array}{l}\text { Store } \\
\text { Atmospherics }\end{array}$ & 6 & 2.25 & 7.26 & 52.00 & 4.86 & 5 \\
\hline $\mathbf{3}$ & Store appeal & 6 & 1.95 & 6.43 & 58.43 & 4.93 & 4 \\
\hline & & & & & 62.65 & 4.98 & 2 \\
\hline $\mathbf{4}$ & Promotion & 6 & 1.16. & 4.22 & 66.58 & 4.95 & 3 \\
\hline $\mathbf{5}$ & $\begin{array}{l}\text { Store } \\
\text { accessibility }\end{array}$ & 7 & 1.06 & 3.94 & & \\
\hline Scale: & 7= extremely important; 4= moderately important; 1= extremely unimportant & &
\end{tabular}

The total variance explained by the extracted store image factors is $66.58 \%$, which indicates that the other $33.42 \%$ is accounted for by extraneous variables that do not constitute part of this study. The percentage of variance explained complies with Malhotra's (2010) prescription that the cumulative percentage of variance extracted by the factors should be at least $60 \%$. The summated mean scores ranged between $(\bar{x}=\geq 4.93)$ and $(\bar{x} \leq 5.08)$. These scores represent an average inclination towards the 'important' position on the Likert scale, which demonstrates that all store image factors were considered to be important by sportswear shoppers. Among the five store image factors extracted, sales assistance $(\bar{x}=5.08)$ emerged as the most important to whereas store appeal $(\bar{x}=4.93)$ was the least important to sportswear consumers.

\section{Correlation Analysis}

In the present study, Spearman's correlations were employed to test the associations between store image factors, store satisfaction and loyalty. The results are reported in Table 3.

Table 3. Correlations: Store Image factors, Store Satisfaction and Customer loyalty

\begin{tabular}{|c|c|c|c|c|c|c|c|}
\hline Factors & $\begin{array}{l}\text { Factor } 1 \text { Sales } \\
\text { assistance }\end{array}$ & $\begin{array}{l}\text { Factor } 2 \text { Store } \\
\text { atmospherics }\end{array}$ & $\begin{array}{c}\text { Factor } 3 \text { Store } \\
\text { appeal }\end{array}$ & $\begin{array}{c}\text { Factor } 4 \\
\text { Promotions }\end{array}$ & $\begin{array}{c}\text { Factor } 5 \text { Store } \\
\text { accessibility }\end{array}$ & $\begin{array}{c}\text { Store } \\
\text { satisfaction }\end{array}$ & $\begin{array}{c}\text { Customer } \\
\text { loyalty }\end{array}$ \\
\hline Factor 1 & 1 & $.684^{* *}$ & $.613^{* *}$ & $.423^{* * *}$ & $.650^{* *}$ & $-.029 *$ & $-.003^{* *}$ \\
\hline Factor 2 & $.684^{* *}$ & 1 & $.723^{* *}$ & $.515^{* *}$ & $.708^{* *}$ & .114 & .062 \\
\hline Factor 3 & $.613^{* *}$ & $.723^{* *}$ & 1 & $.536^{* *}$ & $.782^{* *}$ & $.043^{* *}$ & $.045^{* *}$ \\
\hline Factor 4 & $.423^{* *}$ & $.515^{* *}$ & $.536^{* *}$ & 1 & $.570^{* *}$ & $.169^{* *}$ & $.187^{* *}$ \\
\hline Factor 5 & $.650^{* *}$ & $.708^{* *}$ & $.782^{* *}$ & $.570^{* *}$ & 1 & $.005^{* *}$ & $-.037^{* *}$ \\
\hline Satisfaction & -.029 & .071 & .043 & $.169^{* *}$ & .005 & 1 & $.685^{* *}$ \\
\hline Loyalty & -.003 & .085 & .045 & $.187^{* *}$ & -.037 & $.685^{* *}$ & 1 \\
\hline
\end{tabular}

The correlation matrix (Table 3) exposes that all marked correlations are either significant at $\mathrm{p}<0.01$ or $\mathrm{p}<0.05$, thus indicating that statistically significant positive relationships existed among the dimensions of store selection. Inter factor correlations between the store image factors ranged from $r=0.423$ to $r=782$, which signifies the existence of moderate to strong relationships between the factors. Store satisfaction showed positive relationships with factor three (store appeal) $(r=0.043)$, factor four (promotion/brand availability) $(r=0.169)$, and factor five (store accessibility) $(r=0.005 ; \mathrm{p}=)$. However, the relationship between store satisfaction and sales assistance was negative $(r=-0.29 ; \mathrm{p}=0.05)$. Additionally, a strong positive correlation $(\mathrm{r}=0.685 ; \mathrm{p}<0.01)$ was observed between store satisfaction and customer loyalty. This demonstrates that satisfaction with a particular store positively influences customer loyalty to the store. Hence, the correlations offer support to convergence as positive relationships were found among the variables under study. 


\section{Regression Analysis}

In order to establish the amount of variance in store satisfaction that can be explained by the five store image dimensions, a standard multiple regression analysis was performed. The five store selection dimensions were used as independent variables and store satisfaction was entered into the regression model as the dependent variable. The results of the regression model are presented in Table 4.

Table 4. Regression model 1 - Store selection dimensions and store satisfaction

\begin{tabular}{lccc}
\hline Dependent variable: Store satisfaction & & T & Sig \\
\hline \multicolumn{1}{c}{ Independent variable (Predictors) } & Beta & -2.008 & .045 \\
\hline Factor:1 (Sales assistance) & -.167 & -2.605 & .419 \\
Factor:2 (Atmospherics) & -.178 & 1.828 & .068 \\
Factor:3 (Store appeal) & .136 & 2.161 & .031 \\
Factor:4 (Promotion) & .150 & -.267 & .789 \\
Factor:5 (Store accessibility) $\quad-.018$ & Adjusted $\mathrm{R}^{2}=0.047$ &
\end{tabular}

The five store image factors explained approximately $46 \%\left(R^{2}=0.459\right)$ of the variance in store satisfaction. Although the regression model was significant at $\mathrm{p}<0.000$, an inspection of the individual independent revealed that factor 4 , (promotion) $(\beta=0.150$ ), and factor 3 (store appeal) ( $\beta=0.136)$ were the only predictors of store satisfaction. On the other hand, Beta coefficients indicated that factor 1 (sales assistance) ( $\beta=-0.167$ ); factor 2 and factor 6 (store accessibility) ( $\beta=-0.018$ ), were statistically insignificant, which demonstrates that they are not instrumental in generating store satisfaction.

\section{Regression Analysis: Store Satisfaction and Customer Loyalty}

In addition to examining the relationships between the established dimensions of store selection and store satisfaction, regression analysis was also conducted in order to establish whether a predictive relationship existed between store satisfaction and customer loyalty. Store satisfaction was entered into the regression model as an independent variable and customer loyalty was entered into the model as a dependent variable. The results are reported in Table 5.

Table 5. Regression model 2: Store satisfaction and customer loyalty

\begin{tabular}{|c|c|c|c|}
\hline \multicolumn{4}{|l|}{ Dependent variable: Customer loyalty } \\
\hline Independent variable (Predictors) & Beta & $\mathbf{T}$ & sig \\
\hline Store satisfaction & .686 & 20.779 & .000 \\
\hline
\end{tabular}

The regression model indicates that approximately $47 \%\left(\mathrm{R}^{2}=0.470\right)$ of the variance in customer loyalty can be attributed to store satisfaction. Store satisfaction was statistically significant, signifying its predictive relationship with customer loyalty.

\section{DISCUSSION}

Hypothesis $\mathbf{H}_{1}$ was not supported and was therefore rejected in the present study since the regression model revealed that factor 1 (sales assistance) was statistically insignificant ( $\beta=-0.167 ; \mathrm{t}=-2.008 ; \mathrm{p}=0.045$ ). This result demonstrates that sales assistance is, in the context of this study, not a predictor of customer satisfaction. Thus, customer satisfaction cannot be indexed on sales assistance. The results of the current study are in line with empirical observations made by Moore and Carpenter's (2006) who found that sales assistance was inferior to other attributes such as price, quality and selection of merchandise in influencing customer satisfaction. Additionally, a ranking of store image factors conducted by Kwon and Lennon (2011) placed merchandise and store environment in more prominent positions, well ahead of sales assistance. Studies conducted by Baker, Parasuraman, Grewal and Voss (1994) and Kursunluoglu (2011) also established that the sales assistance had little impact on store choice. However, the fact that available assistance from store personnel did not make a significant impact on store 
satisfaction does not make the dimension unimportant as choice behaviour is rather a complex phenomenon such that it would be unrealistic to assume that all variables can account for substantial proportion of variability (Babin \& Attaway, 2000). As suggested by Carpenter and Brosdahl (2011), shoppers still appreciate input from knowledgeable store personnel in selecting appropriate merchandise within an apparel context. Wang and Ha (2011) also acknowledge that keeping customers informed about mark-downs through credible advertising facilitates higher customer satisfaction and loyalty. Therefore, it remains important for apparel retail store to employ sufficient numbers of competent shop attendants.

Hypothesis, $\mathbf{H}_{\mathbf{2}}$ did not find support and was therefore rejected in the current study as the results of the regression analysis show that store atmospherics was statistically insignificant ( $\beta=-0.178 ; \mathrm{t}=-2.605 ; \mathrm{p}=0.419)$. This denotes that store atmospherics did not predict customer satisfaction in the current study. These findings find support in a previous study by Theodoridis and Chatzipangiotou (2009) which concluded that store atmospherics were insignificant predictors of satisfaction. Another study conducted by Han and Ryu (2009) also revealed that store atmospherics had indirect rather than direct influence on consumer's shopping behaviour. Sands, Oppewal and Beverland (2009) further specify that although store atmospherics affect in-store shopper behaviour, it may not always be the case as shoppers vary in terms of what appeals to them and compels them to make a purchase. However, there is a discrepancy between the findings of the present study and some previous studies (Nguyen \& LeBlanc, 2002; Hsu \& Chang, 2008) which link store atmospherics to customer satisfaction. Thang and Tan (2003:198) also suggest that pleasing store atmospherics which offer comfortable, fashionable and stylish gratifications that contribute to customers' sense of well-being in the store tend to enhance consumer preferences for the store. Therefore, well-planned retail atmospherics factors should be established in order to create positive consumer behaviour towards the store and the kind of behaviour that can be linked to increased levels of browsing and increased levels of consumer spend in store (Noad \& Rogers, 2008).

In the current study, Hypothesis $\mathbf{H}_{\mathbf{3}}$ was supported and is therefore accepted, based on the fact that factor 3 (store appeal) emerged as a statistically significant predictor ( $\beta=0.136 ; \mathrm{t}=1.828 ; \mathrm{p}=0.06$ ) of store satisfaction. Accordingly, the degree of store appeal reflects the level of customer satisfaction with the store. Store appeals are an important approach for alerting consumers about special offers and gift vouchers available. In line with this view, Hyllegard, Ogle and Yan (2009) substantiate that both in-store and out-of-store appeals have the potential of shaping the consumer's purchase intentions. Jefkins (2000) suggests that retailers should implement store appeals which will present the most credible and persuasive selling message to the right prospects for the product or service at the lowest possible cost. Scott and Walker (2010) further posit that more customers can be drawn to the store via extensive in-store and out-of-store credible advertising. Chiliya, Herbst and Roberts-Lombard (2009) acknowledge that word-of-mouth (WOM) communication amongst black consumers is the most credible form of advertising. As such, it is imperative for retail shop owners to ensure that both the internal as well as external designs of their shop are of such a standard that appeals to the targeted customers.

Hypothesis $\mathbf{H}_{\mathbf{4}}$ received support and was accepted in this study because factor 4 (promotion) emerged as a statistically significant predictor $(\beta=0.200 ; \mathrm{t}=2.161 ; \mathrm{p}=0.00$ ) of store satisfaction. This result illustrates that the extent to which the apparel retail store promotes itself or its products is an important indicator of the degree to which customers are satisfied with that store. Generally, promotional programmes are implemented to influence consumers' perceptions, attitudes and behaviour towards the store (Lewison, 1997). Montaner, de Chernatony and Buil (2011) underscore that appropriate use of the promotional mix typically stimulates higher store satisfaction levels in the customers, resulting in greater purchase intentions on store brands. Leischnig, Schwertfeger and Geigenmueller (2011) found that promotion has the potential to create unique customer shopping experiences which might also result in greater devotion by customers to a particular store. Ha, John, Janda and Muthalu (2011) further indicated that spending on promotion is good for an organisation in multiple ways beyond helping immediate sales, because it can influence key desirable affective, cognitive, as well as behavioural outcomes. It is crucial then, for retail outlets to offer more attractive and interesting promotional programmes during different seasons, in order to augment the satisfaction levels of their customers (Rajagopal, 2011). 
Hypothesis $\mathbf{H}_{5}$ was not supported and is rejected since the results of the study revealed that factor 5 (store accessibility) was statistically insignificant ( $\beta=-0.018 ; \mathrm{t}=-.267 ; \mathrm{p}=0.789$ ). As such, store accessibility does not predict store satisfaction, in the current context. Consistently, store accessibility did not feature as a benefit in a previous study undertaken by Terblanche (1999) on super regional shopping centers in South Africa. Yilmaz, Aktas and Celik (2007) also draw attention to a unique group of customers who take shopping as a hobby, to the extent that store proximity or easy access of the store ceases to be a motivating factor to them. Typically, such customers may travel great distances for shopping on a regular basis, just for the fun of it (Jain \& Bagdare, 2009). It has to be noted though, that the results of the current study contradict the findings of observations of a number of previous scholars (Clodfelter, 2010; Kimani et al., 2012; Huang, Oppewal \& Mavondo, 2012) who maintain that the location of the store may, in some cases, be the deciding factor for consumers, for the basic reason of convenience. The unorthodox result of the present study result could be attributed to the fact that the study was conducted in selected shopping malls in Gauteng Province in which a majority of the sports-wear retail stores are located. Hence, accessibility was a given and did not impact on store satisfaction, since the stores were easily accessible to shoppers.

Hypothesis $\mathbf{H}_{6}$ was supported as store satisfaction emerged as a significant predictor ( $\beta=0.686 ; \mathrm{t}=20.779$; $\mathrm{p}=0.00$ ) of customer loyalty. This finding demonstrates that the level of store satisfaction among store customers is a reflection of the extent to which these customers are loyal to that store. Consistent with this finding, Wong and Sohal (2003) posit that if a consumer is satisfied with a store, there is a greater likelihood that the consumer will revisit the store. Lamb et al. (2004) add that satisfied customers are likely to remain loyal to the store, which enhances profitability. Marx and Erasmus (2006) also draw attention to the fact that if consumers are satisfied with a purchase experience, the possibility of repeat purchase behaviour and customer loyalty increases. A number of previous studies (Salim, 2009; Tu, Mei-Lien \& Heng-Chi, 2011; Curtis, Abratt, Rhoades \& Dion, 2011) acknowledged that store satisfaction predicts customer loyalty in retail environments. It appears then that the greater the satisfaction of shoppers with a particular store, the more they are likely to patronise that shop in the future.

\section{LIMITATIONS AND IMPLICATIONS FOR FUTURE RESEARCH}

The results of the present study should be considered within the light of several limitations to the study. First, the findings of study are based on a limited sample of participants who were drawn from three shopping malls only that are located in one province; namely, Gauteng Province. In view of this fact, the findings of the study are not entirely representative of all ethnic groups and regions or provinces, which limit the extent to which the study can be generalised. Second, the findings of the study should also be treated with caution, since a non-probability convenience sampling technique was used, which increased the study's vulnerability to sampling bias. Third, the measurement scales that were used in this study were adapted from other studies that were originally designed and intended for purposes and contexts that differ from those of this study.

The present study is not without implications for further research. First, since the study focused on sports apparel, future studies should be extended to products other than sports apparel. Second, similar studies could be conducted that include other regions of Gauteng, other provinces, other subcultures, social classes and lifestyles. Since the quantitative mode was adopted for this study, future studies could use the mixed method approach in which both qualitative and quantitative approaches are integrated, in order to refine the results. This could provide an in depth understanding of store selection criteria among consumers. Future direction on store selection criteria also requires further refinement of the survey instrument in order to include other store image factors that were excluded from this study. In order to examine improvements to the instrument, longitudinal research could be conducted by replicating the study in similar settings over different time phases. This could provide updated insights on the changing shifts in store selection criteria among consumers of sports apparel. Finally, the data could be tested using a more robust statistical tool, such as structural equation modeling (SEM).

\section{CONCLUSIONS}

The present study examined the relationship between store image factors, store satisfaction and customer loyalty in the purchase of sportswear apparel in Gauteng Province. Using exploratory factor analysis, five key store image dimensions; namely, sales assistance, store atmospherics, store appeal, promotion and store accessibility were 
identified. Among these five factors, sales assistance emerged as the most important factor and store atmospherics emerged as the least important factor to consumers of sports apparel. Medium to strong positive correlations were observed between all five store image factors. As such, an increase in the level of one store image factor results in an increase in the levels of the other factors, and vice versa. Sales assistance was negatively related to store satisfaction. It also emerged that there were weak correlations between store satisfaction and the other four factors; store atmospherics, promotion, store appeal and store accessibility. In the regression analysis, only promotion and store appeal emerged as predictors of store satisfaction. Store satisfaction also emerged a statistically significant predictor of customer loyalty.

\section{MANAGERIAL IMPLICATIONS}

The findings of the present study have several managerial implications which should be highlighted. In general, it is important for apparel retailers to cultivate a thorough understanding of factors influential in store selection among apparel consumers. These unique insights could enable the former to develop appropriate strategies that enhance the levels of patronage and sales in their stores. Retail store managers and marketers should ensure that all sales assistants are equipped with essential skills that will enable them to be more courteous, patient, and efficient when transacting and communicating with customers. Apparel store personnel should exhibit great interpersonal skills while attempting to resolve the requests of customers. Based on the fact that stores with professionally trained, well-mannered and willingness shop attendants are more likely to be patronised by consumers, it becomes paramount for shop attendants to have extensive knowledge of merchandise to serve customers. Additionally, it is necessary for retailers to create a pleasing store atmosphere which will increase consumers' preference of their store. Knowing what atmospheric variables impact on customers' feelings may assist retailers to assemble appropriate marketing strategies to create and maintain a positive shopping experience among customers.

To enhance store appeal, fashionable, stylish and eye-catching store exterior/interior should be treated as an absolute. Exterior features such as store front, entrances, window displays should be continuously refurbished since they are are the first set of cues that consumers use to evaluate a store. Retail store management should also aim at differentiating their stores by adjusting their interior variables with a blend of inducing in-store appeals such as mirrors, music, lightings, digital displays monitors and attractive decorations. Since pomotion was considered important by customers when shopping for sportswear, special offers and mark-downs on branded items are essential for retailers to stimulate sales. Upcoming sales of branded items should be announced well ahead of time, in order to give consumers enough time to prepare.

On the overall, in the highly competitive contemporary retailing industry and continued economic pressure, store management should strive to identify important factors that determine sore choice on a continuous basis. As shown by the study, an understanding of what motivate shoppers to select one store amongst other stores, and the identification of in-store and out-of-store activities encourages consumers to stay store loyal are key critical success factors in retail businesses.

\section{REFERENCES}

Aaker, D.A., Kumar, V. \& Day, G.S. (2007). Marketing research. $9^{\text {th }}$ ed. Hoboken: John Wiley \& Sons.

Amine, A., \& Cadenat, S. (2003). Efficient retail assortment: a consumer choice evaluation perspective. International Journal of Retail \& Distribution Management, 31(10), 486-497.

Aspfors, E. (2010). Customer perception of service, store image and product assortment: from an interior store perspective. Unpublished Master's Dissertation. Finland: Vaasa University of Applied Sciences.

Babin, B.J., \& Attaway, J.S. (2000). Atmospheric affect as a tool for creating value and gaining share of customers. Journal of Business Research, 49(2), 91-99.

Baker, J., Parasuraman, A., Grewal, D., \& Voss, G.B. (2002). The influence of multiple store environment cues on perceived merchandise value and patronage intentions. Journal of Marketing, 66(2), 120-141.

Belch, G.E. \& Belch, M.A. 2001. Advertising and promotion. $5^{\text {th }}$ ed. New York: McGraw-Hill.

Berman, B., \& Evans, J.R. (2010). Retail management: a strategic approach. $11^{\text {th }}$ ed. Upper Saddle River, New Jersey: Prentice-Hall.

Bowen, J.T., \& Chen, S.L. (2001). The relationship between store loyalty and customer satisfaction. International Journal of Contemporary Hospitality Management, 13(5), 213-217.

Copyright by author(s); CC-BY 
Bianchi, C.C. (2009). Investigating consumer expectations of convenience-store attributes in emerging markets: evidence in Chile. Journal of International Consumer Marketing, 21, 309-320.

Blackwell, R.D. \& Miniard, P.W., \& Engel, F.J. (2006). Consumer behaviour. $10^{\text {th }}$ ed. Singapore: Thomson SouthWestern.

Bloemer, J., \& De Ruyter, K. (1998). On the relationship between store image, store satisfaction and store loyalty. European Journal of Marketing, 32(5/6), 499-513.

Broekemier, G., Marquardt, R., \& Gentry, J.W. (2008). An exploration of happy/sad and liked/disliked music effects on shopping intentions in a woman's clothing store service setting. Journal of Service Marketing, 22(1), 59-67.

Cant, C., Brink, A., \& Brijball, S. (2006). Consumer behaviour. Cape Town: Juta \& Co.

Carpenter, J.M. \& Brosdahl, D.J.C. 2011. Exploring retail format choice among US males. International Journal of Retail \& Distribution Management, 39(12), 886-898.

Carpenter, J. M., \& Moore, M. (2006). Consumer demographics, store attributes, and retail format choice in the US grocery market. Journal of Retail \& Distribution Management, 34(6), 434-452.

Chan, J.K.Y., \& Chan, P.Y.L. (2008). Merchandise display affects store image. European Advances in Consumer Research, 8, 408-414.

Chen-Yu, J.H., \& Seock, Y.K. (2002). Adolescents' clothing purchase, information sources, and store selection criteria: a comparison of male/female and impulse/non-impulse shoppers. Family \& Consumer Sciences Research Journal, 31(1), 50-77.

Chiliya, N., Herbst, G., \& Roberts-Lombard, M. (2009). The impact of marketing strategies on profitability of small grocery shops in South Africa townships. African Journal of Business Management, 3(3), 70-79.

Churchill, G.A. \& Brown, T.J. (2007). Basic marketing research. $6^{\text {th }}$ ed. Mason: Thomson South-Western.

Clodfelter, R. (2010). Retail buying: From basics to fashion. $3^{\text {rd }}$ ed. New York: Fairchild Books.

Curtis, T., Abratt, R., Rhoades, D., \& Dion, P. (2011). Store loyalty, repurchase and satisfaction: a meta-analytical review. Dissatisfaction \& Complaining Behavior, 24, 1-26

Dalwadi, R., Rathod, H.S., \& Patel, A. (2010). Key retail store determining consumers' perceptions: an empirical study on consumers of retail store located in Ahmedabad (Gujarat). South Indian Education Society (SIES) Journal of Management, 7(1), 20-34.

De Wulf, K., \& Odekerken-Schroder, G. (2003). Assessing the impact of a retailer's relationship effort on consumers: attitudes and behaviour. Journal of Retailing \& Consumer Services, 10(2), 95-108.

De Klerk, M.H., \& Lubbe, S. (2008). Female consumer's evaluation of apparel quality: exploring the importance of aesthetics. Journal of Fashion Marketing \& Management, 12(1), 36-50.

Du Preez, R., Visser, E., \& Van Noordwyk, H.J. (2008a). Store image: towards conceptual model part 1. South African Journal of Industrial Technology, 34(2), 50-58.

Du Preez, R., Visser, E., \& Van Noordwyk, H.J. (2008b). Store image: scale implementation part 3. South African Journal of Industrial Technology, 34(2), 69-78.

Du Preez, R., \& Van Der Vyver, J. (2010). Managerial and consumer perceptions of apparel store image: a congruity analysis. Management Dynamics, 19(1), 11-24.

East, R., Hammond, K., Harris, P., \& Lomax, W. (2000). First store loyalty and retention. Journal of Marketing Management, 16(4), 307-325.

Evanschitzky, H., Iyer, G.R., \& Caemmerer, B. (2008). Dimensions of satisfaction in retail settings: A research note. Journal of Relationship Marketing, 7(3), 275-285.

Fiore, A.N., Yah, X., \& Yoh, E. (2000). Effects of a product display and environmental fragrancing on approach responses and pleasurable experiences. Journal of Psychology \& Marketing, 17(1), $27-54$.

Foxall, G.R., \& Yani-de-Soriano, M.M. (2005). Situational influences on consumers' attitudes and behaviour. Journal of Business Research, 58(4), 518-525.

Ghosh, P., Triphati, V., \& Kumar, A. (2010). Customer expectations of store attributes: a study of organized retail outlets in India. Journal of Retail \& Leisure Property, 9(1), 75-87.

Grewal, D., Baker, J., Levy, M., \& Voss, B.V. (2003). The effects of wait expectations and store atmosphere evaluations on patronage intentions in service-intensive retail stores. Journal of Retailing, 79(4), 259-268.

Grover, G., Dutta, S., \& Chakraborty, S. (2011). Transaction specific approach of customer satisfaction: A study of an organised retail outlet in Jalandhar, Punjab, India. Journal of Economic Development, Management IT, Finance \& Marketing. 3(1), 1-17.

Gundala, R.R. (2010). Retail store image: a study of the Cyprus clothing industry. International Journal of Management \& Marketing Research, 3(3), 67-81.

Ha, H., John, J., Janda, S., \& MUTHALY S. (2011). The effects of advertising spending on brand loyalty in services. European Journal of Marketing, 45(4), 673-691. 
Han, H., \& Ryu, K. (2009). The roles of physical environment, price perception, and customer satisfaction in determining store loyalty in the restaurant industry. Journal of Hospitality \& Tourism Research, 33(4), 487-510.

Hair, J.F., Black, W.C., Babin, J.B., Anderson, R.E., \& Tatham, R.L. (2010). Multivariate data analysis. $6^{\text {th }}$ ed. Upper Saddle River, New Jersey: Prentice Hall.

Hassan, Y., Muhammad, N. M. N., \& Abu Bakar, H. (2010). Influence of shopping orientation and store image on patronage of furniture store. International Journal of Marketing Studies, 2(1), 175-184.

Hoffman, K.D., \& Turley, L.W. (2002). Atmospherics, services encounters and consumer decision making: an integrative perspective. Journal of Marketing Theory \& Practice, 10(3), 33-47.

Hsu, J.L., \& Chang, K.M. (2008). Purchase of clothing and its linkage to family communication and lifestyles among young adults. Journal of Fashion Marketing \& Management, 12(2), 147-163

Hu, H. (2011). Chinese consumers' store image formation and its impact on patronage behaviour. Academy of Marketing Studies Journal, 15(2), 83-102.

Hu, H., \& Jasper, C.R. (2006). Social cues in the store environment and their impact on store image. International Journal of Retail \& Distribution Management, 34(1), 25-48.

Huang, Y., Oppewal, H., \& Mavondo, F. (2012). The influence of ethnic attributes on ethnic consumer choice of service outlet. European Journal of Marketing, 47(5/6), 1-44.

Huddleston, P., Whipple, J., Mattick, R.N., \& Lee, S.J. (2009). Customer satisfaction in food retailing: comparing speciality and conventional grocery stores. International Journal of Retail \& Distribution Management, 37(1), 63-80.

Hyllergard, K., Ogle, J., \& Yan, N. (2009). The impact of advertising message strategy fair labour v. sexual appeal upon Gen Y consumers' intent to patronize an apparel retailer. Journal of Fashion Marketing \& Management, 13(1),109-127.

Ibrahim, H., \& Najjar, F. (2008). Assessing the effects of self-congruity, attitudes and customer satisfaction on customer behavioural intentions in retail environment. Marketing Intelligence \& Planning, 26(2), 207-227.

Jain, R., \& Bagdare, S. (2009). Determinants of customer experience in new format retail stores. Journal of Marketing \& Communication, 5(2), 34-44.

Jefkins, F. (2000). Advertising. $4^{\text {th }}$ ed. London: Pearson Education Limited.

Jones, M.A., Reynolds, K.E., \& Arnold, M.J. (2006). Hedonic and utilitarian shopping value: investigating differential effects on retail outcomes. Journal of Business, 59(9), 974-981.

Karpova, E., Hodges, N. N., \& Tullar, W. (2007). Making sense of the market. An exploration of apparel consumption practices of the Russian consumer. Journal of Fashion Marketing \& Management, 11(1), 106-121.

Kim, Y. K. (2002). Consumer value: an application to mall and internet. International Journal of Retail \& Distribution Management, 30(12), 595-602.

Kimani, S.W., Kagira, E.K., Kendi, L., Wawire, C.M., \& Fourier, U.J. (2012). Shoppers perception of retail service quality: supermarkets versus small convenience shops (Dukas) in Kenya. Journal of Management \& Strategy, 3(1), 55-66.

Knox, S.D., \& Denison, T.J. (2000). Customer loyalty: its impact on retail revenue: an empirical study of purchasing behaviour in the UK. Journal of Retailing \& Consumer Services, 7(1), 33-45.

Koksal, M.H. (2007). Consumer behaviour and preferences regarding children's clothing in Turkey. Journal of Fashion Marketing \& Management, 11(1), 69-81.

Kotler, P. (1974). Atmospherics as a marketing tool. Journal of Retailing, 49(4), 48-64.

Kotler, P., \& Keller, K.L. (2006). Marketing management. $12^{\text {th }}$ ed. New Jersey: Prentice-Hall.

Kucukemiroglu, O. (1999). Market segmentation by using consumer lifestyle dimensions and ethnocentrism: an empirical study. European Journal of Marketing, 33(5/6), 470-487.

Kursunluoglu, E. (2011). Customer service effects on customer satisfaction and customer loyalty: a field research in shopping centers in Izmir City-Turkey. International Journal of Business \& Social Sciences, 2(17), 52-59.

Kwon, W.S. \& Lennon, S.J. 2011. Assessing college women's associations of American speciality apparel brands. Journal of Fashion Marketing \& Management, 15(2), 242-256.

Lamb (Jr), C.W., Hair (Jr), J.F., McdanieL, C., Boshoff, C., Terblanche, N., Elliot, R., \& Klopper, H.B. (2010). Marketing. $4^{\text {th }}$ ed. Cape Town: Oxford University Press.

Leischnig, A., Schwertfeger, M., \& Geigenmueller, A. (2011). Do shopping events promote retail brands? International Journal of Retailing \& Distribution Management, 39(8), 619-634.

Levy, M., \& Weitz, B. A. (2009). Retailing management. $8^{\text {th }}$ ed. University of Florida: McGraw-Hill.

Lewison, D.M. (1997). Retailing. $6^{\text {th }}$ ed. New Jersey: Prentice-Hall.

Lichtenstein, D.R., Burton, S., \& Netemeyer, R.G. (1997). An examination of deal proneness across sales promotion types. Journal of Retailing, 73(2), 283-297. 
Ligas, M., \& Chaudhuri, A. (2012). The moderating roles of shopper experience and store type on the relationship between perceived merchandise value and willingness to pay a higher price. Journal of Retailing \& Consumer Services, 19(2), 249-258.

Lu, P.H., \& Lukoma, I.G. (2011). Customer satisfaction towards retailers. Unpublished Masters Degree Dissertation. Gotland: Gotland University.

Lu, Y., \& Rucker, M. (2006). Acquisition via single vs. multiple channels: College students' perspectives in the US and China. Journal of Retailing \& Consumer Services, 13(1), 35-50.

Malhotra, N.K. (2010). Marketing research: an applied orientation. $6^{\text {th }}$ ed. New Jersey: Prentice-Hall.

Martinez-Ruiz, M.P, Jimenez-Zarco, A.I., \& Izquierdo-Yusta, A. (2010). Customer satisfaction's key factors in Spanish grocery stores: evidence from hypermarkets and supermarkets. Journal of Retailing \& Consumer Services, 17(4), 278-285.

Marx, N.J.M.M., \& Erasmus, A. (2006). An evaluation of the customer service in supermarkets in Pretoria East, Tshwane Metropolis, South Africa. Journal of Family Ecology \& Consumer Sciences, 34, 56-68

Mattsson, K. (2009). Customer satisfaction in the retail market. Unpublished Master's Dissertation. Finland: Vaasa University of Applied Sciences.

McDaniel, C., \& Gates, R. (2010). Marketing research essentials. $7^{\text {th }}$ ed. USA: John Wiley \& Sons Inc.

McKeever, K. (2011). Visual Merchandising. How to make your store sparkle this Christmas. [Internet]. http://www.retail-week.com/store/visual merchandising. Retrieved on 26 August 2013.

Moerloose, C., Antioco, M., Lindgreen, A., \& Palmer, R. (2005). Information kiosks: the case of the Belgian retail sector. International Journal of Retail \& Distribution Management, 33(6), 472-490.

Montaner, T., De Chernatony, L., \& Buil, I. (2011). Consumer response to gift promotions. Journal of Product \& Brand Management, 20(2), 101-110.

Morschett, D., Swobona, B., \& Foscht, T. (2005). Perception of store attributes and overall attitudes towards grocery retailers: the role of shopping motives. International Review of Retail, Distribution \& Consumer Research, 15(4), 423-447.

Moschis, G.P., Ferguson, J.L., \& Zhu, M. (2011). Mature consumers' selection of apparel and footwear brands and department stores. International Journal of Retail \& Distribution Management, 39(10):785-801.

Moye, L.N., \& Giddings, V.L. (2002). An examination of the retail approach-avoidance behaviour of older apparel consumers. Journal of Fashion Marketing \& Management, 6(3), 259-276.

Noad, J., \& Rogers, B. (2008). The importance of retail atmospherics in B2B retailing: the case of BOC. International Journal of Retail \& Distribution Management, 36(12), 1002-1014.

Nazish, S., Rizvi, Z., \& Malik, S. (2011). Impact of sales promotion on organizations' profitability and consumer's perception in Pakistan. Interdisciplinary Journal of Contemporary Research in Business, 3(5), 296-310.

Nguyen, N., \& Leblanc, G. (2002). Contact personnel, physical environment and the perceived corporate image of intangible services by new clients. International Journal of Service Industry Management, 13(3), $242-262$.

North, E.J., \& Croeser, V. (2006). The influence of background music on patrons in a South African coffee shop setting: an exploratory study. International Retail \& Marketing Review, 291, 1-10.

Oates, B., Shufeldt, L., \& Vaught, B. (1996). A psychographic study of the elderly and retail store attributes. Journal of Consumer Marketing, 13(6), 14-27.

Oh, J., Fiorito, S.S., Cho, H., \& Hofacker, C.F. (2008). Effects of design factors on store image and expectation of merchandise quality in web-based store. Journal of Retailing \& Consumer Services, 15(4), 237-249.

Petermans, A., \& Van Cleempoel, K. (2010). Designing a retail store environment for the mature market: a European perspective. Journal of Interior Design, 35(2), 21-36.

Prasad, C.J., \& Aryasri, A.R. (2011). Effect of shopper attributes on retail format choice behaviour for food and grocery retailing in India. International Journal of Retail \& Distribution Management, 39(1), 68-86.

Rajagopal. J. (2011). Impact of radio advertisements on buying behaviour of urban commuters. International Journal of Retail \&Distribution Management, 39(7), 480-503.

Reutterer, T., \& Teller, C. (2009). Store format choice and shopping trip types. International Journal of Retail \& Distribution Management, 37(8), 695-710.

Rigopoulou, I.D., \& Tsiotsou, R.H. (2008). Shopping orientation-defined segment based on store-choice criteria and satisfaction. Journal of Marketing Management, 24(9/10), 979-995.

Saeed, I., Niazi, M.A., Arif, M. \& Jehan, N. 2011. Antecedents of customer satisfaction and its outcomes: a study of Pakistan service sector. Interdisciplinary Journal of Contemporary Research in Business, 3(8), 877-889.

Salim, L. 2009. Indonesian customer loyalty factors for modern retailing market. International Journal of Social \& Human Sciences, 3, 709-716.

Sands, S., Oppewal, H., \& Beverland, M. (2009). The effects of in store themed events on consumer store choice decisions. Journal of Retailing \& Consumer Services, 16(5), 386-395. 
Saraswat, A., Mammen, T., Aagja, J.P., \& Tewari, R. (2010). Building store brands using image differentiation. Journal of Indian Business Research, 2(3), 166-180.

Schiffman, L.G., \& Kanuk, L.L. (2009). Consumer behaviour. $9^{\text {th }}$ ed. New Jersey: Pearson Education International.

Scott, P., \& Walker, J. (2010). Advertising, promotion, and the competitive advantage of interwar British department stores. Economic History Review, 63(4), 1105-1128.

Shao, A.T. (2002). Marketing research: an aid to decision making. Cincinnati: South Western Thompson Learning.

Sherman, E., Mathur, A., \& Smith, R.B. (1997). Store environment and consumer purchase behaviour: mediating role of consumer emotions. Psychology \& Marketing, 14(4), 361-378.

Sinha, P.K., \& Banerjee, A. (2004). Store choice behaviour in an evolving market. International Journal of Retail \& Distribution Management, 32(10), 482-494.

Sinha, P.K., Banerjee, A. \& Uniyal, D.P. 2002. Deciding where to buy: store choice behaviour of Indian shoppers. Vikalpa Management Journal, 27(2), 13-28.

Solvang, B.K. (2007). Satisfaction, loyalty, and repurchase: A study of Norwegian customers of furniture and grocery stores. Journal of Customer satisfaction, Dissatisfaction \& Complaining Behavior, 20, 110-122.

Terblanche, N.S. (1999). The perceived benefits derived from visits to a super-regional shopping centre: an exploratory study. South African Journal of Business Management, 30(4), 141-146.

Terblanche, N.S., \& Boshoff, C. (2006). The relationship between a satisfactory in-store shopping experience and retailer loyalty. South African Journal of Business Management, 37(2), 33-43.

Thang, D.C.L., \& Tan, B.L.B. (2003). Linking consumer perception to preference of retail stores: an empirical assessment of the multi-attributes of store image. Journal of Retailing \& Consumer Service, 10(4),193-200.

Thenmozhi, S.P., \& Dhanapal, D. (2012). Store choice behaviour in retail outlets. Global Management Review, 6(2):1023.

Tlapana, T.P. (2009). Store layout and its impact on consumer purchasing behaviour at convenience stores in Kwa-Mashu. Unpublished Masters Degree Dissertation, Masters. Durban: Durban University of Technology.

Theodoridis, P.K., \& Chatzipanagiotou, K.C. (2009). Store image attributes and customer satisfaction across different customer profiles within the supermarket sector in Greece. European Journal of Marketing, 43(5/6), 708-734.

Tu, Y.T., Mei-Lien, L.Y., \& Heng-Chi, C. (2011). The effect of service quality, customer Perceived value and satisfaction on loyalty. Journal of Economics \& Behavioral Studies, 3(3), 198-212.

Van Der Vyver, J. (2008). The importance of store image dimensions in apparel retail: Customer and management perceptions. Unpublished Masters Dissertation. Cape Town: University of Stellenbosch, Stellenbosch.

Veloutsou, C., Gilbert, R., Moutinho, L., \& Goode, M. (2005). Measuring transaction specific satisfaction in services: Are the measures transferable across Cultures? European Journal of Marketing, 39(5/6), 606-628.

Venter, P.F., \& Dhurup, M. (2005). Consumer perceptions of supermarket service quality: scale development and validation. South African Journal of Economic \& Management Science, 8(4), 424-436.

Vipul, P. (2010). Impact of demographic factors on consumer response to sales promotions: an empirical study. Advances in Management, 3(10), 60-65.

Visser, E., Du Preez, R., \& Van Noordwyk, H.J. (2006). Importance of apparel store image attributes: perceptions of female consumers. South African Journal of Industrial Technology 32(3), 49-62.

Volle, P. (2001). The short-term effect of store-level promotions on store choice, and the moderating role of individual variables. Journal of Business Research, 53(2), 63-73.

Wang, C.H., \& Ha, S. (2011). Store attributes influencing relationship marketing: a study of department stores. Journal of Fashion Marketing \& Management, 15(3), 326-344.

Wong, A., \& Sohal, A. (2003). A critical incident to the examination of customer relationship management in a retail chain: an exploratory study. Qualitative research: An International Journal, 6(4), 248-262.

Wirtz, J., Mattila, A.S., \& Tan, R.L.P. (2007). The role of arousal congruency in influencing consumers' satisfaction evaluations and in-store behaviors. International Journal of Service Industry Management, 18(1), 6-25.

Yan, R.N., \& Eckman, M. (2009). Are lifestyle centers unique? Consumers' perceptions across locations. International Journal of Retail \& Distribution Management, 37(1), 24-42.

Yi, Y., \& La, S. (2004). What influences the relationship between customer satisfaction and repurchase intentions? Investigating the effects of adjusted expectations and customer loyalty. 2004. Journal of Psychology \& Marketing, 21(5), 351-373.

Yilmaz, V., Aktas, C. \& Celik, H.E. 2007. Development of a scale for measuring consumer behavior in store choice. Anadolu University Journal of Social Sciences, 7, 171-185.

Zikmund, W.G., \& Babin, B.J. (2010). Essentials of marketing research. $4^{\text {th }}$ ed. Ohio: South-Western Cengage Learning. 